\title{
EFEKTIVITAS BUNGA KENANGA (Cananga odorata Hook.F \& TH) SEBAGAI HEPATOPROTEKTOR PADA TIKUS PUTIH ( Rattus norvegicus) YANG DIINDUKSI CARBON TETRA CHLORIDE
}

\author{
(THE EFFECTIVENESS OF YLANG FLOWER (Cananga odorata Hook.F \& TH) AS \\ HEPATOPROTECTOR IN WHITE RATS (Rattus norvegicus) WHICH INDUCED BY \\ CARBON TETRTACHLORIDE)
}

\author{
NI NYOMAN WAHYU UDAYANI ${ }^{1}$, HERLEEYANA MERIYANI ${ }^{1}$, KETUT AGUS ADRIANTA ${ }^{1}$ \\ ${ }^{1}$ Akademi Farmasi Saraswati Denpasar, Jalan Kamboja No.11A, Denpasar, Bali
}

\begin{abstract}
Abstrak: Tujuan dari penelitian ini adalah untuk mengetahui efek yang dimiliki oleh ekstrak Bunga kenanga (Cananga odorata Hook.F \& TH) terhadap penurunan kadar SGOT dan SGPT tikus yang diinduksi Carbon Tetra Chloride dan untuk mengetahui seberapa besar pemberian ekstrak Bunga kenanga (Cananga odorata Hook.F \& TH) dapat menghambat kerusakan hati dengan mengamati gambaran histopatologi pada tikus yang diinduksi oleh Carbon Tetra Chloride. Dosis yang terbukti efektif sebagai hepatoprotektor yaitu dosis $400 \mathrm{mg} / \mathrm{kg}$ dan dosis $800 \mathrm{mg} / \mathrm{kgBB}$ dengan $\mathrm{p}<0,05$ serta ditandai dengan penurunan kadar SGOT dan SGPT. Sedangkan hasil histopatologi hepar tikus, menunjukkan rerata jumlah nekrosis yang berbeda antara kelompok satu, kelompok dua, kelompok tiga, dan kelompok empat secara berturut-turut menggunakan uji kemaknaan One Way ANOVA 16,7 $(\mathrm{p}=0,001), 32,75(\mathrm{p}=0,001), 28,8 \quad(\mathrm{p}=0,001), 15,5 \quad(\mathrm{p}=0,001), 12(\mathrm{p}=0,001)$. Dilanjutkan dengan uji komparasi menggunakan One Way ANOVA untuk melihat perbedaan yang bermakna antar kelompok perlakuan, sehingga diperoleh hasil P1:P2 ( $=0,001), P 1: P 3 \quad(p=0,001), P 1: P 4(p=0,157)$, $\mathrm{P} 1: \mathrm{P} 5(\mathrm{p}=0,001)$. Hasil penelitian rerata nekrosis menunjukkan bahwa ekstrak etanol bunga kenanga bali dosis $200 \mathrm{mg} / \mathrm{kg}$ BB (P3) belum efektif sebagai hepatoprotektor. Dosis yang terbukti efektif sebagai hepatoprotektor adalah dosis $400 \mathrm{mg} / \mathrm{kg}$ BB (P4) karena memiliki efek yang sama seperti obat hepatoprotektor yang beredar di pasaran (P1) dan dosis $800 \mathrm{mg} / \mathrm{kg}$ BB. Namun, setelah dianalisis berdasarkan histopatologi hepar tikus, dosis $800 \mathrm{mg} / \mathrm{kg}$ BB menunjukkan hasil yang lebih baik.
\end{abstract}

Kata kunci: Bunga kenanga, hepatoprotektor, karbon tetraklorida, SGOT/SGPT, Histopatologi Hepar

\begin{abstract}
The aims of this study are to know the effect of ylang flower extract (Cananga odorata Hook.F \& $\mathrm{TH})$ towards the decrease of SGOT and SGPT levels in rats induced by Carbon Tetra Chloride and to find out how much Cananga odorata extract can inhibit liver damage by observing the histopathology of hepatic rats which induced by Carbon Tetra Chloride. The dose proved to be effective as a hepatoprotector are dose of $400 \mathrm{mg} / \mathrm{KgBW}$ and dose of $800 \mathrm{mg} / \mathrm{KgBW}$ with $\mathrm{p}<0.05$ and characterized by decreased levels of SGOT and SGPT. While histopathologic results of hepatic rats, showed the average number of different necrosis amount between the first group, second group, third group, and the fourth group respectively using One Way ANOVA significance test, 16,7 ( $\mathrm{p}=0,001), 32,75(\mathrm{p}=0,001), 28,8(\mathrm{p}=0,001), 15,5(\mathrm{p}=0,001), 12(\mathrm{p}=0,001)$. Continued by comparative test using One Way ANOVA to see the significant difference between treatment groups, so that P1: P2 ( $p=0,001), P 1: P 3(p=0,001), P 1: P 4(p=0,157), P 1: P 5(p=0,001)$. The result of average amount of necrosis research showed that the ylang flower extract of dose $200 \mathrm{mg} / \mathrm{kgBW}$ (P3) was not effective as hepatoprotector. The dose proven effective as a hepatoprotector is a dose of $400 \mathrm{mg} / \mathrm{kgBW}$ (P4) because it has the same effect with the common hepatoprotector drug (P1) and the dose of $800 \mathrm{mg} / \mathrm{kgBW}$. However, after the rat liver histopathology analysis, the doses of $800 \mathrm{mg} / \mathrm{kgBW}$ showed better results.
\end{abstract}

Keywords: ylang Flower, hepatoprotector, carbon tetrachloride, SGOT / SGPT, Hepar Histopathology

\section{PENDAHULUAN}

Hati merupakan organ terbesar dalam tubuh manusia. Hati memiliki beberapa fungsi penting, seperti: (1) pengolahan metabolik nutrien utama, seperti karbohidrat, lemak, dan protein; (2) detoksifikasi atau degradasi zat-zat sisa, hormon, obat dan senyawa asing lainnya; (3) sintesis berbagai protein plasma, antara lain protein yang berperan untuk pembekuan darah, untuk

\footnotetext{
•email korespondensi: agusaick@gmail.com
} 
mengangkut hormon tiroid, steroid dan kolesterol dalam darah; (4) penyimpanan glikogen, lemak, besi, tembaga dan vitamin; (5) pengaktifan vitamin D; (6) perombakan sel darah merah; (7) ekskresi kolesterol dan bilirubin; (8) sekresi empedu (Lestari, 2008; Crawford, 2007; Nguyen, 2006).

Sebagai organ metabolisme, hati merupakan tempat utama untuk memetabolisme obat dan senyawa kimia toksik (radikal bebas), dimana hasil akhir reaksi ini menjadi senyawa yang tidak aktif dan lebih larut dalam air, sehingga dapat diekskresi melalui empedu atau urine. Apabila hati mengalami paparan zat toksik berlebih (misal: senyawa kimia, obat, alkohol), maka keracunan/kerusakan pada hepar cenderung terjadi, dengan gejala awal hepatotoksik ditandai dengan peningkatan enzim transaminase dalam serum. Enzim aminotransferase yang diukur, antara lain SGPT (serum glutamate pyruvate transaminase) atau ALT (alanin transaminase) dan SGOT (serum glutamate oksaloasetat transaminase) atau AST (aspartate transaminase) (Aldredge et al, 2013).

Keanekaragaman tanaman herbal yang dimiliki Indonesia serta ketersediaannya disekitar masyarakat sangat berpotensi untuk dimanfaatkan sebagai obat-obatan dalam upaya memelihara, mempertahankan dan mengobati masalah kesehatan dikalangan masyarakat. Pemanfaatan herbal sebagai obat merupakan warisan budaya yang didasari oleh keterampilan, pengetahuan dan pengalaman yang secara turun-temurun diwariskan oleh generasi sebelumnya (Wijaya, 2000). Dari beberapa penelitian disebutkan bahwa kurang lebih sekitar 7500 tanaman yang tumbuh di wilayah Indonesia dapat dipergunakan untuk pengobatan (Wiartha, 2011). Secara empiris tanaman herbal diketahui mempunyai berbagai efek farmakologis seperti efek analgesik, antipiretik, anti inflamasi, anti oksidan, anti kolesterol, antidiabetes, anti hipertensi dan lain sebagainya.

Bunga kenanga (Cananga odorata Hook.F \& TH) merupakan salah satu tanaman yang bisa digunakan sebagai obat tradisional. Ekstrak bunga kenanga memiliki efek sebagai antioksidan, antimikroba, antibiofilm, anti inflamasi, antivektor, repellent, antidiabetes, antifertilitas dan antimelanogenesis (Tan et al, 2015). Bunga kenanga diketahui mengandung 3, 4, 5, 7 tetrahidroksi flavon yang mampu menurunkan ROS intraseluler dengan berikatan dengan satu radikal bebas yang kemudian Ikatan tersebut akan dapat menstabilkan peroksi yang membuat sinergi aktivasi akan berkurang. Sacchetti et al., 2006 mengatakan bunga kenangamengandung antara lain saponin, Flavonoida, minyak atsiri, senyawa polifenol yaitu $\beta$-kariofilen, $\alpha$-terpineol, linalool, methyl benzoate, benzil salysilat, terpineol, myristicin, dan benzil benzoat. Bunga kenanga diduga memiliki aktivitas hepatoprotektor berdasarkan kemampuannya sebagai antioksidan dan antiinflamasi. Salah satu mekanisme hepatoprotektor dalam mengatasi kerusakan hati yaitu dengan menstabilkan radikal bebas yang merupakan salah satu faktor yang berperan dalam kerusakan jaringan hati. Di samping itu kemampuan sebagai antiinflamasi juga dapat berperan penting terhadap penghambatan kerusakan hati, dimana gangguan kerusakan sel hati selalu diawali dengan adanya peradangan/ inflamasi pada sel hati (Dipiro et al, 2008).

Namun demikian belum terdapat penelitian ataupun informasi ilmiah yang valid untuk mendukung bahwa bunga kenanga dapat mencegah, menghambat atau memperbaiki kerusakan hepar yang disebabkan oleh agen hepatotoksik masih sangat terbatas. Dengan demikian muncul pertanyaan apakah ekstrak Bunga kenanga (Cananga odorata Hook.F \& TH) berkhasiat untuk memperbaiki kerusakan hepar yang diinduksi oleh agen sitotoksik. Sehingga perlu dilakukan penelitian untuk membuktikan bahwa ekstrak Bunga kenanga (Cananga odorata Hook.F \& TH) secara peroral mempunyai khasiat menurunkan kadar SGOT dan SGPT darah pada tikus putih serta memperbaiki kerusakan hepar tikus yang diinduksi oleh oleh agen hepatotoksik $\left(\mathrm{CCl}_{4}\right)$ melalui gambaran histopatologinya.

\section{BAHAN DAN METODE}

Rancangan Penelitian. Penelitian ini merupakan penelitian eksperimental dengan rancangan Posttest Only Randomized Control Design dengan Rancangan Acak Lengkap (RAL).

Alat. Alat yang digunakan terdiri atas alat-alat kaca yang umumnya ada di laboratorium toples kaca, cawan porselen, oven (SOV $70 \mathrm{~B}$ ), corong penyaring, corong buchner,water bath, kertas saring, kain flannel, gunting, aluminium foil, tempat makan dan minum tikus, kandang tikus, sonde oral, disposable syringe $3 \mathrm{ml}$ (Terumo), neraca analitik, sendok tanduk, sarung tangan, masker, mortir,stamper,tissue., timbangan tikus, sonde oral, spektofotometer, spuit tuberkulin, waterbath, mikro hematokrit, microtube, rak dan tabung reaksi untuk menampung darah, kapas steril, bejana kaca, mikro pipet, sentrifuge, gunting bedah, pinset. 
Bahan. Bahan-bahan yang digunakan dalam penelitian ini adalah bunga kenanga (Cananga odorata Hook.F \& TH), etanol (merk Brataco), tikus jantan berumur 3-4 bulan dengan berat badan 100-200 gram dan sehat, pakan tikus, $\mathrm{CCl}_{4}$, placebo (CMC Na), aquadest, tablet curcuma, aquadest.

Metode. Bunga Kenanga Bali diperoleh dari daerah Sibanggede Badung. Bunga kenanga bali kemudian disortasi basah, kemudian dikeringkan dan di blender. Pembuatan ekstrak etanol bunga kenanga bali dilakukan dengan cara dimaserasi menggunakan etanol. Setelah diperoleh filtratnya maka ekstrak etanol bunga kenanga bali dipekatkan menggunakan oven.

Hewan coba yang digunakan adalah tikus galur wistar jantan yang sesuai dengan sampel yang telah ditentukan dalam penelitian, hepatoprotektor, dengan spesifisitas:

a. Tikus (Rattus norvegicus) dewasa jenis kelamin jantan, galur Wistar

b. Umur 3-4 bulan

c. Berat badan tikus $180-200 \mathrm{~g}$.

Dengan kriteria drop out adalah tikus yang mati selama penelitian berlangsung. Perhitungan besar sampel menggunakan rumus Federer didapatkan jumlah sampel yang digunakan pada penelitian sebanyak 5 ekor untuk tiap kelompok perlakuan. Untuk mencegah drop out maka sampel penelitian ditambahkan sebanyak 10\% sehingga jumlah sampel yang digunakan menjadi 5,5 dan dibulatkan menjadi 6 ekor. Untuk penelitian ini menggunakan 7 ekor tikus per kelompoknya, sehingga total hewan coba yang digunakan adalah 35 ekor. Sebelum mulai penelitian tikus diaklimatisasi selama 30 hari.

Sebagai penginduksi kerusakan hati digunakan karbon tetraklorida. Penelitian mengenai efek hepatoprotektor dari bunga kenanga dilakukan dengan mengamati kadar $S G O T / S G P T$ dan gambaran histopatologi hepar tikus. Data yang diperoleh akan disajikan secara deskriptif dan secara statistika dengan taraf kepercayaan $95 \%$.

\section{HASIL DAN PEMBAHASAN}

Pengukuran kadar SGOT dan SGPT dilakukan menggunakan spektrofotometer dalam satuan IU/L dengan skala rasio. Setelah darah diambil dan ditampung di tabung diamkan hingga membeku pada suhu kamar $\left(25^{\circ} \mathrm{C}-30^{\circ} \mathrm{C}\right)$ kemudian dilakukan sentrifuge dengan kecepatan $3500 \mathrm{rpm}$ selama 10 menit untuk mendapatkan supernatan yang mengandung serum. Penggunaan serum dalam penelitian ini karena serum lebih tahan lama dibandingkan plasma. Serum tersebut kemudian diperiksa kadar SGOT dan SGPT-nya dengan metode kinetik menggunakan spektrofotometri. Hasil pengukuran SGOT/SGPT dapat dilihat pada tabel 1 .

\begin{tabular}{|c|c|c|c|}
\hline No & Kelompok & SGOT & SGPT \\
\hline 1 & \multirow{7}{*}{$\mathrm{P} 1$} & 53,40 & 242,90 \\
\hline 2 & & 75,70 & 245,00 \\
\hline 3 & & 89,40 & 292,00 \\
\hline 4 & & 95,80 & 325,00 \\
\hline 5 & & 88,00 & 250,90 \\
\hline 6 & & 80,00 & 230,70 \\
\hline 7 & & 88,20 & 275,40 \\
\hline 1 & \multirow{7}{*}{$\mathrm{P} 2$} & 170,00 & 826,00 \\
\hline 2 & & 161,10 & 794,00 \\
\hline 3 & & 115,20 & 576,00 \\
\hline 4 & & 188,40 & 769,30 \\
\hline 5 & & 150,00 & 675,00 \\
\hline 6 & & 150,40 & 684,40 \\
\hline 7 & & 155,00 & 695,70 \\
\hline 1 & \multirow{7}{*}{ P3 } & 144,10 & 466,90 \\
\hline 2 & & 185,30 & 768,30 \\
\hline 3 & & 142,90 & 665,60 \\
\hline 4 & & 142,90 & 675,70 \\
\hline 5 & & 151,00 & 655,40 \\
\hline 6 & & 240,00 & 755,00 \\
\hline 7 & & 160,00 & 555,00 \\
\hline 1 & \multirow{7}{*}{ P4 } & 64,70 & 234,00 \\
\hline 2 & & 67,60 & 234,40 \\
\hline 3 & & 63,50 & 221,00 \\
\hline 4 & & 61,50 & 240,30 \\
\hline 5 & & 85,70 & 330,70 \\
\hline 6 & & 66,50 & 355,00 \\
\hline 7 & & 70,65 & 271,00 \\
\hline 1 & \multirow{7}{*}{ P5 } & 45,00 & 235,00 \\
\hline 2 & & 62,70 & 284,00 \\
\hline 3 & & 60,10 & 281,00 \\
\hline 4 & & 52,20 & 237,00 \\
\hline 5 & & 88,40 & 355,40 \\
\hline 6 & & 80,00 & 330,00 \\
\hline 7 & & 75,00 & 281,70 \\
\hline
\end{tabular}

Untuk melakukan pemeriksaan gambaran histopatologi kerusakan hepar oleh $\mathrm{CCl}_{4}$ dan pengaruh pemberian ekstrak etanol bunga kenanga, maka harus dilakukan pembuatan preparat histologi hepar tikus terlebih dahulu, dimana pembuatan preparat dan analisa histologi hepar dilakukan di Laboratorium Patologi FKH UNUD.

Adapun variabel yang diamati pada pemeriksaan histopatologi jaringan hepar tikus, antara lain: degenerasi melemak dan nekrosis. 
Data kualitatif yang diperoleh yaitu berupa pengamatan ada/tidaknya variabel tersebut. Pengamatan dilakukan pada 4 lapang pandang mikroskopik yang berbeda dengan menggunakan mikroskop cahaya binokuler dengan pembesaran 400 kali (Kardena, 2011). Data kuantitatif didapat dengan cara menghitung jumlah sel hati yang mengalami degenerasi hidrofik, degenerasi melemak dan nekrosis pada tiap sampel Tikus.

\section{Tabel 2. Hasil Perhitungan Jumlah Sel Hepar} Nekrosis

\begin{tabular}{|c|c|c|c|c|c|c|c|}
\hline \multirow{2}{*}{ No } & \multirow{2}{*}{$\begin{array}{l}\text { Perlaku } \\
\text { an }\end{array}$} & \multicolumn{6}{|c|}{$\begin{array}{c}\text { Pemeriksaan Nekrosis Hepatosit } \\
\text { Pasca Pemberian } \mathrm{CCl}_{4}\end{array}$} \\
\hline & & I & II & II & $\begin{array}{l}\mathbf{I} \\
\mathbf{V}\end{array}$ & $\begin{array}{c}\text { TOTA } \\
\mathbf{L}\end{array}$ & $\begin{array}{l}\text { Rata } \\
\text {-rata }\end{array}$ \\
\hline 1 & \multirow{7}{*}{ P1 } & 21 & 17 & 15 & 14 & 67 & 16,75 \\
\hline 2 & & 18 & 15 & 18 & 17 & 68 & 17 \\
\hline 3 & & 15 & 16 & 20 & 15 & 66 & 16,5 \\
\hline 4 & & 19 & 18 & 17 & 16 & 70 & 17,5 \\
\hline 5 & & 16 & 15 & 15 & 17 & 63 & 15,75 \\
\hline 6 & & 16 & 17 & 19 & 16 & 68 & 17 \\
\hline 7 & & 19 & 14 & 16 & 17 & 66 & 16,5 \\
\hline 1 & \multirow{7}{*}{$\mathrm{P} 2$} & 34 & 29 & 37 & 32 & 132 & 33 \\
\hline 2 & & 27 & 35 & 32 & 33 & 127 & 31,75 \\
\hline 3 & & 34 & 31 & 36 & 26 & 127 & 31,75 \\
\hline 4 & & 36 & 32 & 33 & 37 & 138 & 34,5 \\
\hline 5 & & 37 & 35 & 27 & 30 & 129 & 32,25 \\
\hline 6 & & 33 & 32 & 35 & 31 & 131 & 32,75 \\
\hline 7 & & 35 & 35 & 31 & 32 & 133 & 33,25 \\
\hline 1 & \multirow{7}{*}{ P3 } & 26 & 27 & 25 & 31 & 109 & 27,25 \\
\hline 2 & & 29 & 30 & 28 & 30 & 117 & 29,25 \\
\hline 3 & & 31 & 25 & 31 & 33 & 120 & 30 \\
\hline 4 & & 24 & 32 & 25 & 29 & 110 & 27,5 \\
\hline 5 & & 32 & 27 & 29 & 32 & 120 & 30 \\
\hline 6 & & 33 & 31 & 28 & 25 & 117 & 29,25 \\
\hline 7 & & 33 & 29 & 25 & 28 & 115 & 28,75 \\
\hline 1 & \multirow{7}{*}{ P4 } & 23 & 20 & 19 & 18 & 80 & 20 \\
\hline 2 & & 17 & 16 & 15 & 16 & 64 & 16 \\
\hline 3 & & 15 & 14 & 14 & 17 & 60 & 15 \\
\hline 4 & & 15 & 13 & 12 & 10 & 50 & 12,5 \\
\hline 5 & & 11 & 12 & 23 & 11 & 57 & 14,25 \\
\hline 6 & & 19 & 16 & 11 & 10 & 56 & 14 \\
\hline 7 & & 14 & 20 & 18 & 15 & 67 & 16,75 \\
\hline 1 & \multirow{7}{*}{ P5 } & 20 & 19 & 14 & 11 & 64 & 16 \\
\hline 2 & & 10 & 10 & 12 & 12 & 44 & 11 \\
\hline 3 & & 9 & 11 & 9 & 13 & 42 & 10,5 \\
\hline 4 & & 10 & 9 & 10 & 12 & 41 & 10,25 \\
\hline 5 & & 13 & 14 & 12 & 10 & 49 & 12,25 \\
\hline 6 & & 15 & 10 & 11 & 16 & 52 & 13 \\
\hline 7 & & 16 & 11 & 10 & 9 & 46 & 11,5 \\
\hline
\end{tabular}

Untuk melihat apakah terdapat perbedaan rerata $S G O T / S G P T$ antar kelompok dilakukan uji oneway ANOVA dengan taraf kepercayaan 95\%. Hasil uji One Way ANOVA SGOT dapat dilihat pada tabel 3 dan hasil komparasi antar kelompok perlakuan terhadap kadar $S G O T$ dapat dilihat pada tabel 4 .

Tabel 3. Hasil Uji one-way ANOVA antar kelompok terhadap Kadar SGOT dan SGPT

\begin{tabular}{cccc}
\hline $\begin{array}{c}\text { Kelompok } \\
\text { Perlakuan }\end{array}$ & N & $\begin{array}{c}\text { Rerata } \\
\text { Kadar SGOT } \\
(\boldsymbol{\mu} / \mathbf{L})\end{array}$ & $\mathbf{p}$ \\
\cline { 1 - 2 } P1 Kontrol Positif & 7 & 81.50 & \\
\cline { 1 - 2 } P2 Kontrol Negatif & 7 & 155.72 & \\
\cline { 1 - 2 } P3 (200mg/kgBB) & 7 & 166.60 & \\
\cline { 1 - 2 } P4 (400mg/kgBB) & 7 & 68.59 & \\
\cline { 1 - 2 } P5 (800mg/kgBB) & 7 & 66.20 & \\
\hline
\end{tabular}

Pada hasil uji tersebut dapat diambil kesimpulan bahwa terdapat perbedaan yang bermakna terhadap kadar SGOT pada kelima kelompok perlakuan.

Tabel 4. Uji Komparasi Antar Kelompok Perlakuan Terhadap Kadar SGOT

\begin{tabular}{lcc}
\hline $\begin{array}{c}\text { Kelompok yang } \\
\text { dibandingkan }\end{array}$ & $\begin{array}{c}\text { Beda } \\
\text { rerata }\end{array}$ & p \\
\hline Perlakuan 1 (+) Perlakuan 2(- & $-74,22857$ & 0.001 \\
) & $-85,10000$ & 0.001 \\
Perlakuan 3 & 12,90714 & 0.267 \\
Perlakuan 4 & 15,30000 & 0.190 \\
Perlakuan 5 & & \\
\hline Perlakuan 2 (-) Perlakuan 3 & $-10,87143$ & 0,349 \\
Perlakuan 4 & 87,13571 & 0,001 \\
Perlakuan 5 & 89,52857 & 0,001 \\
\hline Perlakuan 3 Perlakuan 4 & 98,00714 & 0,001 \\
Perlakuan 5 & 100,40000 & 0,001 \\
\hline Perlakuan 4 Perlakuan 5 & 2,39286 & 0,835
\end{tabular}

Berdasarkan tabel 4 dapat dilihat bahwa perlakuan 1 (control positif) tidak berbeda bermakna dengan perlakuan 3,4 dan 5. Perlakuan 2 (control negative) berbeda bermakna dengan perlakuan 4 dan 5 . Hal ini menunjukkan bahwa ekstrak bunga kenanga kelompok 4 dan 5 memiliki aktivitas hepatoprotektor jika ditinjau dari perbedaan rerata $S G O T$.

Demikian juga dengan hasil pemeriksaan $S G P T$. Terdapat perbedaan bermakna perlakuan 4 dan 5 terhadap control negative dan tidak terdapat perbedaan bermakna dengan control positif sehingga, ekstrak bunga kenanga kelompok 4 dan 5 memiliki aktivitas hepatoprotektor ditinjau dari kadar SGPT. Hasil uji komparasi antar kelompok perlakuan terhadap kadar SGPT dapat dilihat pada tabel 5. 


\begin{tabular}{lcc}
\multicolumn{3}{c}{$\begin{array}{c}\text { Tabel 5. Uji Komparasi Antar Kelompok } \\
\text { Perlakuan Terhadap Kadar SGPT }\end{array}$} \\
\hline \multicolumn{1}{c}{ Kelompok Kelompok } & $\begin{array}{c}\text { Beda } \\
\text { rerata }\end{array}$ & P \\
\hline Perlakuan 1(+) Perlakuan & $-451,21429$ & 0.001 \\
2(-) & $-382,85714$ & 0.001 \\
Perlakuan 3 & $-3,50000$ & 0.926 \\
Perlakuan 4 & $-20,31429$ & 0.592 \\
\hline Perlakuan 5 & 68,35714 & 0,078 \\
\hline Perlakuan 2 (-) Perlakuan 3 & 447,71429 & 0,001 \\
Perlakuan 4 & 430,90000 & 0,001 \\
\hline Perlakuan 5 & 379,35714 & 0,001 \\
\hline Perlakuan 3 Perlakuan 4 & 362,54286 & 0,001 \\
\hline Perlakuan 5 & $-16,81429$ & 0,657 \\
\hline Perlakuan 4 Perlakuan 5 & & \\
\hline
\end{tabular}

Tabel 6. Hasil Uji one-way ANOVA antar kelompok rerata nekrosis sel hepar

\begin{tabular}{|c|c|c|c|}
\hline $\begin{array}{c}\text { Kelompok } \\
\text { subjek }\end{array}$ & $\mathbf{n}$ & $\begin{array}{c}\text { Rerata } \\
\text { nekrosis } \\
\text { hepar }\end{array}$ & $\mathbf{p}$ \\
\hline $\begin{array}{c}\text { Perlakuan } 1 \\
(+)\end{array}$ & 7 & 16,7 & \multirow{5}{*}{0,0001} \\
\hline Perlakuan $2(-)$ & 7 & 32,75 & \\
\hline Perlakuan 3 & 7 & 28,8 & \\
\hline Perlakuan 4 & 7 & 15,5 & \\
\hline Perlakuan 5 & 7 & 12 & \\
\hline
\end{tabular}

Pada hasil uji tersebut dapat diambil kesimpulan bahwa terdapat perbedaan yang bermakna terhadap rerata nekrosis hepar pada kelima kelompok perlakuan.

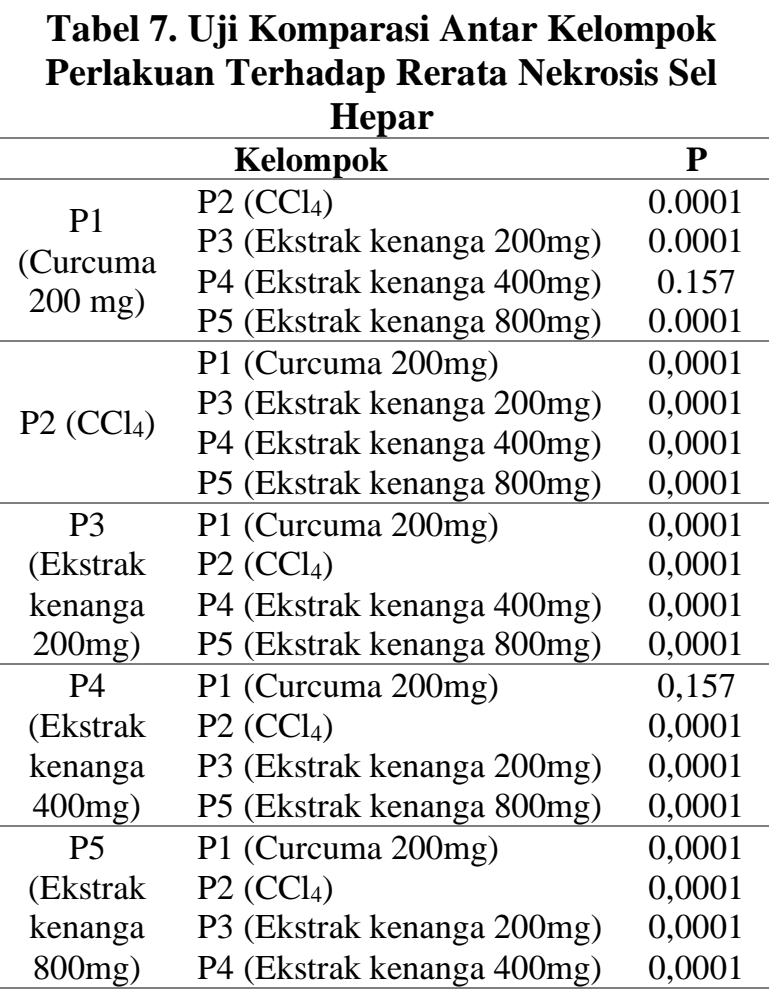

\section{SIMPULAN}

Dari hasil penelitian yang telah dilakukan, dapat ditarik kesimpulan bahwa:

1. Dari hasil penelitian, ekstrak etanol bunga kenanga bali (Cananga ordorata Lam.) mempunyai aktivitas sebagai hepatoprotektor dapat dibuktikan dari penurunan kadar SGOT (Serum Glutamic Oxaloacetic Transaminase) dan SGPT (Serum Glutamic Pyruvic Transaminase) pada tikus putih jantan (Rattus norvegicus) yang dinduksi karbon tetraklorida setelah pemberian ekstrak etanol bunga kenanga Bali.

2. Ekstrak bunga kenanga bali menunjukkan keefektifan pada dosis $400 \mathrm{mg} / \mathrm{kgBB}$ dan $800 \mathrm{mg} / \mathrm{kgBB}$. Namun setelah dianalisis berdasarkan gambaran histopatologi hepar tikus, dosis $800 \mathrm{mg} / \mathrm{kgBB}$ menunjukkan hasil yang lebih baik.

\section{DAFTAR PUSTAKA}

Adrianta, Agus.2013. Ekstrak Etanol Bunga Kenanga (Cananga odorata Hook.F \& TH) Menurunkan Kadar Tumor Necrosis Factor Alpha (TNF- $\alpha$ ) dan Memperbaiki Profil Lipid pada Tikus Putih (Rattus norvegicus) yang Dislipidemia. Universitas Udayana. Denpasar

Aldredge, B.K., et al 2013. Koda-Kimble And Young's Applied Therapeutics the Clinical Use of Drug 10th Edition. Lippincott Williams and Wilkins: USA

Chen, Qingshan., Zan, Qi., Li, Ying., Zhao, Liang., Zang, Hai., dan Zhang, Guoqing. 2017. Schisandra Lignan Extract Protects against Carbon Tetrachloride-Induced Liver Injury in Mice by Inhibiting Oxidative Stress and Regulating the NF-Kb and JNK Signaling Pathways. Department of Pharmacy, Shanghai Eastern Hepatobiliary, Second Military Medical University, Shanghai. China

Dahlan, MS. 2011. Statistik untuk Kedokteran dan Kesehatan. Salemba Medika. Jakarta

Dipiro, J. T., R. L. Talbert, G. C. Yee, G. R. Matzke, B. G. Wells, L. M. Posey, 2008, Pharmacotherapy A Pathophysiologic Approach Sixth edition. New York: McGrawHill 3th Ed., Oxford Science Publications, Oxford, P. 547-550. 
Fung F. Carbon Tetrachloride and Chloroform. In: Poisoning and Drug Overdose 5th Edition. Olson Kent, Editor. Mc Graw Hill Lange. California. 2007.p.153-154

Guyton, AC. And Hall, J.E. 2007. Buku Ajar Fisiologi Kedokteran, Edisi 9. EGC. Jakarta

Halliwell B. 1991. Reactive oxygen species in living systems. Source biochemistry and role in human decease. Am J. Med. 91: 110-115.

Halliwell, B, Gutteridge, J.M.C. 1999. Free Radicals in Biology and Medicine,

Hanafiah, K.A. 2004. Rancangan Percobaan: teori dan aplikasi. Ed. Rev., Cet 9. Jakarta: Pt Raja Grafindo Persada. Halaman 9.

Indrakumar, Selvi V., Gomathi, R., Karpagam, S. 2012. Evaluation of antimicrobial activity of Cananga odorata (LAM.) Hook.F \& Thompson leaf extract: An invitro study. Dept of Botany: Queen Marry's College India. Cit. Adrianta, Agus.2013. Ekstrak Etanol Bunga Kenanga (Cananga odorata Hook.F \& TH) Menurunkan Kadar Tumor Necrosis Factor Alpha (TNF- $\alpha$ ) dan Memperbaiki Profil Lipid pada Tikus Putih (Rattus norvegicus) yang Dislipidemia. Universitas Udayana. Denpasar.Dipicu Karbon Tetrachlorida. Jurnal Veteriner; 2011 Maret. Vol. 12 No. 1: 34-39.

Kardena I M, Winaya Oka BI. Kadar Perasan Kunyit yang Efektif Memperbaiki Kerusakan Hati Mencit yang Dipicu Karbon Tetrachlorida. Jurnal Veteriner; 2011 Maret. Vol. 12 No. 1: 34-39. kenanga (Cananga odorata Hook.F \& TH). Jurnal Farmaka Vol 5 No. 1, April 2007.

Kumar S., Free radicals and antioxidants: human and food system, Adv Appl SciRes. 2011; 2:129-35

Kumar V, Abbas A, Fausto N. Tissue Renewal, Repair, and Regeneration. Dalam: Robbins Pathologic Basis of Disease. 8th Edition. Philadelphia: Elsevier Saunders. 2010. p.93-95

Miryanti, A., Sapei, L., Budiono, K. dan Indra, S. 2011. Ekstraksi Antioksidan dari Kulit Buah Manggis. Laporan Penelitian. Lembaga Penelitian dan Pengabdian Kepada Masyarakat Universitas Katolik Parahyangan, Bandung.
Moelyono, M.W., Yasmiwar, S., Marina, T., 2007. Analisis minyak atsiri bunga kenanga (Cananga odorata Hook.F \& TH). Jurnal Farmaka Vol 5 No. 1, April 2007.

Nguyen, T, Lingappa, V.R. 2006. Patophysiology of Disease: An Introduction to Clinical Medicine. McGraw-Hill Medical, P. 394-400.

Panjaitan, R.G.P, Handharyani, E., Chairul, Masriani, Zakiah, Z., Manalu, W., Pengaruh Pemberian Karbon Tetraklorida terhadap Fungsi Hati dan Ginjal Tikus, Makara, Kesehatan, Volume 11, No.1, Juni 2007: 11-16

Pocock, S. 2008. Clinical Trials: A Practical Approach. Chichester: John Wiley \& Sons. p. 128-129. Res. 2011; 2:129-35.

Sacchetti, G., Silvia, M., Mariavittoria, M., Scaglianti, M., Manfredini, S., Matteo, R., Renato, B. 2006. Comparative evaluation of 11 essential oils of different origin as functional antioxidants, antiradicals and antimicrobials in foods. Dipartimento delle Risorse Naturali e Culturali, Lab. Biologia farmaceutica \& Biotrasformazioni, Universita' degli Studi di Ferrara, C.so Porta Mare 2, I-44100 Ferrara. Italy.

Simon RP, Patel HV, Kiran K. 2010. Hepatoprotective Activity of Some Plants Extract Against Paracetamol Induced Hepatotoxicity in Rats. J Herb Med Toxic

Soni B, Visavadiya NP, Madamwar D. 2008 Ameliorative Action of Cyanobacterial Phycoerytri on CCl4-Induced Toxicity in Rats. Toxicology. 248: 59-65.

Tan, Loh Teng Hern, Learn Han Lee, Wai Fong Yin, Chim Kei Chan, Habsah Abdul Kadir, Kok Gan Chan, and Bey Hing Goh, 2015, Traditional Uses, Phytochemistry, and Bioactivities of Cananga odorata (YlangYlang), Evidence-Based Complementary and Alternative Medicine, Volume 2015

Valko, marian, dieter Leibfristz, jan Moncol, Mark T.D., Milan Mazur dan Joshua Telser, 2007, Free Radicals and Antioxidant in Normal Phisiologycal Function and Human Disease, The International Journal of Biochemistry\& Cell Biology: 2007 Agustus, vol. 39 (hal 4484). 